DOI 10.4467/2543733XSSB.21.006.13799

INGA KAWKA

Katedra Prawa Europejskiego

Wydział Prawa i Administracji UJ

\title{
POLITYCZNY I IDEOLOGICZNY WYMIAR KONFLIKTU Z 1948 R. MIĘDZY ZWIĄZKIEM SOWIECKIM A JUGOSŁAWIĄ W ŚWIETLE RAPORTÓW BELGIJSKICH DYPLOMATÓW ${ }^{1}$
}

\author{
Political and Ideological Dimension of the 1948 Conflict Between \\ the Soviet Union and Yugoslav in the Light of the Reports of Belgian Diplomats \\ Summary
}

The article concerns the conflict between Tito and Stalin in 1948. The aim of the article is to define how the Belgian diplomacy perceived the split between the Soviet Union and Yugoslavia, and, above all, how it diagnosed its causes and effects. Moreover, the analysis of Belgian diplomatic documents shows the great importance that Western countries attached to the first major breach in the Eastern bloc.

Keywords: Tito-Stalin conflict, Belgian diplomatic documents, Soviet Union, Yugoslavia, Iron Curtain, Cominform

Słowa kluczowe: konflikt Tito-Stalin, belgijskie dokumenty dyplomatyczne, Związek Sowiecki, Jugosławia, żelazna kurtyna, Kominform

\section{Wstęp}

Artykuł dotyczy konfliktu między Titą a Stalinem z 1948 r. Celem artykułu jest określenie, jak dyplomacja belgijska oceniała ówczesną napiętą relację między Związkiem Sowieckim a Jugosławią, a przede wszystkim, w jaki sposób diagnozowała jej przyczyny i skutki. Przedmiotem badań są dokumenty pochodzące z Archiwum Ministerstwa Spraw

${ }^{1}$ Artykuł powstał w wyniku realizacji projektu badawczego nr 2018/30/M/HS3/00153 finansowanego z środków Narodowego Centrum Nauki. 
Zagranicznych Belgii. Obejmują one okres między lipcem a wrześniem 1948 r. i zasadniczo składają się z raportów dyplomatycznych kierowanych do Ministra Spraw Zagranicznych - Paula Henriego Spaaka przez belgijskiego ambasadora w Belgradzie Georgesa Delcoigne'a oraz chargé d'affaires Jacquesa Smeta. Delcoigne - zanim został ambasadorem w Belgradzie, miał już bardzo duże doświadczenie dyplomatyczne. Był zatrudniony jako attaché ambasady w Belgradzie w latach 1920-1923. Następnie udał się do Kopenhagi jako chargé d'affaires (1923-1925), był sekretarzem poselstwa w Atenach (1925-1927) i reprezentował swój kraj jako chargé d'affaires w 1927 r. w Sofii, Belgradzie i ponownie w Sofii. Na tym samym stanowisku pracował w Montevideo od 1932 do 1933 r., rok później w Madrycie, a następnie jako sekretarz poselstwa w latach 1934-1938 w Kairze. W 1937 r. był także członkiem delegacji belgijskiej na konferencji w Montreux, gdzie m.in. rozstrzygnięto kwestię cudzoziemców w Egipcie. W latach 1939-1941 ponownie pełnił funkcję doradcy w Madrycie, a od roku 1941 do 1942 działał w Kairze. W 1942 r. objął najpierw stanowisko chargé d'affaires, a następnie posła w Bejrucie, gdzie pełnił urząd do roku 1944. W latach 1945-1957 był nieprzerwanie ambasadorem w Belgradzie. Belgia wysłała więc do Belgradu wysoko wykwalifikowanego dyplomatę, świadomego zawirowań i zwrotów polityki sowieckiej na Bałkanach.

Belgijskie raporty dyplomatyczne - oprócz analizy sytuacji politycznej - obejmują również przetłumaczone na język francuski oficjalne dokumenty, takie jak: noty, np. adresowane przez Jugosławię do Albanii, rezolucje, np. Komunistycznej Partii Jugosławii (dalej KPJ) i Kominformu oraz niektóre artykuły prasowe. Ich podstawowym odniesieniem jest „Borba” - serbskie czasopismo będące w pierwszym okresie swojego funkcjonowania oficjalnym organem KPJ.

Konflikt między Związkiem Sowieckim a Jugosławią został szczegółowo omówiony w polskiej i zagranicznej literaturze ${ }^{2}$. Nie badano natomiast dociekliwie tego, jak „bratnią kłótnię" postrzegała dyplomacja małych państw zachodnich. Artykuł przybliża to zagadnienie przez ukazanie postawy niewielkiego kraju, wrażliwego na poczynania wielkich mocarstw - Belgii. Analiza belgijskich dokumentów dyplomatycznych pozwala dostrzec, jak wielką wage przykładały państwa zachodnie do pierwszej rysy na spójności bloku wschodniego oraz jak bardzo konflikt Stalin - Tito był dla tych państw zaskakujący ${ }^{3}$.

Jugosławia nie chciała przejść z obozu zwycięzców do obozu krajów zniewolonych i jako jeden z krajów bloku wschodniego walczących po stronie aliantów zdołała tego dokonać, choć pod szyldem komunistycznym. Belgijscy dyplomaci, reprezentujący małe

${ }^{2}$ M. J. Zacharias, Komunizm, federacja, nacjonalizmy. System władzy w Jugosławii 1943-1991, Warszawa 2004; idem, Konflikt radziecko-jugostowiański i przemiany ustrojowe w Jugosławii w latach 1948-1954, Dzieje Najnowsze, 1990, nr 4, s. 25-68; A. Kastory, Jugosławia w polityce Stanów Zjednoczonych, Wielkiej Brytanii i Zwiqzku Sowieckiego 1948-1956, Kraków 2018; M. Deszczyński, Wykluczenie Komunistycznej Partii Jugosławii z Biura Informacyjnego Partii Komunistycznych i Robotniczych, Studia z Dziejów Rosji i Europy Środkowo-Wschodniej, 1993, tom XXVIII, s. 109-133 (tam liczna literatura); Cz. Bobrowski, Socjalistyczna Jugosławia, Warszawa 1957; J. Perović, The Tito-Stalin Split: A Reassessment in Light of New Evidence, Journal of Cold War Studies, 2007, Vol. 9, nr 2, s. 32-63; I. Stawowy-Kawka, Rok 1947 w relacjach butgarsko-jugostowiańskich w kontekście polityki Stalina i sytuacji międzynarodowej, Studia Środkowoeuropejskie i Bałkanistyczne, 2018, tom XXVII, s. 143-164; A. Kadić, The Stalin-Tito Conflict as Reflected in Literature, Slavic Review, 1978, nr 37(1), s. 91-106.

${ }^{3}$ A. Kastory, Jugosławia w polityce Stanów Zjednoczonych, Wielkiej Brytanii i Zwiqzku Sowieckiego $1948-$ 1956, s. 123 i n. 
państwo, z założenia niejako byli uwrażliwieni na poczynania wielkich mocarstw, co przyczyniało się do większego zrozumienia dążeń Jugosławii do obrony własnej suwerenności, mimo dezaprobaty dla jej formy rządów. Jasne było dla nich, że Stalin chciał sprowadzić Jugosławię do poziomu podległych mu krajów wschodnioeuropejskich.

\section{Zarys konfliktu}

Początki kryzysu na linii Stalin - Tito sięgały czasów wojny. Już wtedy, gdy Tito stał na czele Narodowej Armii Wyzwolenia Jugosławii, dochodziło do nieporozumień z Sowietami. Po zakończeniu wojny stały się one jeszcze bardziej widoczne. Nade wszystko Belgradowi nie odpowiadała narzucana przez Sowietów narracja, że wyzwolenie spod okupacji niemieckiej nastąpiło wyłącznie dzięki armii radzieckiej. Wynikało to z faktu, że Tito wyzwolił większą część terytorium Jugosławii samodzielnie, bez pomocy ZSRS i czuł się mniej zależny od władzy sowieckiej niż inne państwa bloku wschodniego ${ }^{4}$. Podkreśla to w książce Rozmowy ze Stalinem Milovan Djilas (Dżilas). W swoich wspomnieniach pisze:

„Poza Albanią Jugosławia była jedynym państwem wschodnioeuropejskim, które oswobodziło się samo spod najazdu hitlerowskiego, a jednocześnie przeprowadziło rewolucję wewnętrzną bez rozstrzygającej pomocy Armii Czerwonej. Posunęło się ono najdalej w dokonywaniu przeobrażeń społecznych, było ponadto położone w najbardziej (...) eksponowanym miejscu bloku sowieckiego"s.

Poza tym w Jugosławii źle widziano obecność sowieckich „doradców technicznych”, którzy zajmowali się nie tylko swoją pracą zawodową, ale werbowali agentów do tajnych służb i próbowali nakłaniać do współpracy wyższych stopniem oficerów armii jugosłowiańskiej. Stalin sprzeciwiał się również industrializacji Jugosławii, wyznaczając jej przede wszystkim rolę państwa rolnego oraz całkowicie chciał podporządkować aspiracje międzynarodowe Tity polityce sowieckiej i jej interesom. Sprawy skomplikowały się, gdy Tito musiał zrezygnować z projektu federacji bałkańskiej, której Rosjanie początkowo sprzyjali; planowana federacja w założeniu miała grupować wokół Jugosławii Albanię i Bułgarię oraz ewentualnie Grecję, gdzie toczyła się wojna domowa. Już w momencie zakończenia wojny Jugosławia prowadziła w Albanii działania zmierzające do zwiększania swoich wpływów politycznych i gospodarczych. Doprowadziło to do podpisania w lipcu 1946 r. układu o współpracy i wzajemnej pomocy między Jugosławią a Albanią, wzmocnionego w listopadzie tego roku o układ wprowadzający unię celną i walutową między tymi państwami. Jednocześnie Jugosławia wysłała do Albanii techników cywilnych i wojskowych. O ścisłości stosunków jugosłowiańsko-albańskich świadczy fakt, że poza budowaną linią kolejową mającą łączyć Szkodrę (Shkodër) z Podgoricą istniały plany wytyczenia jeszcze dwóch innych połączeń kolejowych między Jugosławią a Albanią. Natomiast Główne Dowództwo Polityczne Jugosłowiańskiej Armii miało swojego szkoleniowca w Dowództwie Politycznym Armii Albańskiej. Jugosławia pożyczyła Albanii dwa miliardy dinarów tytułem pomocy gospodarczej i miliard na utrzymanie armii, nie licząc kwot

\footnotetext{
${ }^{4}$ L. Nagy, Démocraties populaires: du bloc soviétique au communisme des patries, Paris1968, s. 111, 112.

${ }^{5}$ M. Djilas, Rozmowy ze Stalinem, Warszawa 1962, s. 109.
} 
na jej wyposażenie ${ }^{6}$. Na początku 1948 r. Tito chciał wprowadzić wojska do Albanii, o czym poinformował Moskwę Enver Hoxha - wówczas zaufany współpracownik Moskwy. Niemniej od maja 1948 r. relacje między Jugosławią a Albanią zaczęły się psuć. Tito podjął decyzję o wysłaniu dwóch dywizji do południowej Albanii, mimo że Stalin, który uważał, że mogłoby to doprowadzić nie tylko do starć między wojskimi jugosłowiańskimi i greckimi, ale również amerykańskimi, nakazał mu ostrożność. Pod koniec stycznia 1948 r. Mołotow wysłał do Tity depeszę z ostrzeżeniem, że Brytyjczycy i Amerykanie mogą interpretować pojawienie się jugosłowiańskiej armii w Albanii jako jej okupację i uznać za pretekst do wkroczenia do tego kraju . Również Djilas w swoich wspomnieniach za bezpośrednią przyczynę zatargu z Moskwą uznawał porozumienie między rządami jugosłowiańskim i albańskim w sprawie stacjonowania dwóch dywizji jugosłowiańskich w Albanii. Pisze on: - „Dywizje już się formowały, pułk myśliwców lotnictwa jugosłowiańskiego był już w Albanii, gdy Moskwa zaprotestowała żywo, odmawiając przyjęcia do wiadomości, iż dywizje jugosłowiańskie potrzebne są do obrony Albanii przed ewentualnym atakiem 'monarchofaszystów' greckich. W swej depeszy do Belgradu Mołotow groził jawnym zerwaniem"s. Stalin od drugiej połowy 1947 r. pracował nad przejęciem władzy nad Albanią z rąk Tity (zwłaszcza gospodarczej), a obecność wojsk jugosłowiańskich w tym kraju mogła zagrozić sowieckim interesom w przejmowaniu nad nim kontroli.

Moskwę niepokoiła również jugosłowiańska polityka wobec Bułgarii. Relacje między tymi państwami były bardzo dobre od momentu podpisania 27 listopada 1947 r. Traktatu o przyjaźni, wspótpracy i wzajemnej pomocy między Ludowa Republika Bułgarii a Federacyjna Ludowa Republikq Jugosławii w Ewksinogradzie, w którym Belgrad zrzekł się reparacji wojennych od Bułgarii. Do podpisania traktatu przygotowały się oba państwa, organizując w dniach od 30 lipca do 1 sierpnia 1947 r. obrady w Bled. Wówczas Tito i Dimitrow podpisali tajną umowę o sposobie włączenia Macedonii Piryńskiej (bułgarskiej) do Macedonii Wardarskiej (jugosłowiańskiej), czyli powiększenia terytorium Ludowej Republiki Macedonii wchodzącej w skład Jugosławii. Natomiast Tito zrzekł się o wiele mniejszych obszarów w Serbii na granicy z Bułgarią, zamieszkałych głównie przez ludność bułgarską, wokół Bosilegradu i Caribrodu oraz kilku wsi nad Timokiem9. O warunkach i terminie zjednoczenia dwóch części Macedonii miały decydować oba kraje, dlatego 1 sierpnia 1947 r. w swym Dzienniku Dimitrow stwierdził:

„Uzgodniliśmy z Tito i przedstawicielem macedońskiej władzy [chodziło o ówczesnego premiera Ludowej Republiki Macedonii - Lazara Koliševskiego - I.K.] ogólną linię w sprawie macedońskiej Republiki. Nie będzie bezpośredniego włączenia Piryńskiego Kraju do Macedońskiej Republiki"10.

${ }^{6}$ J. Smets, Raport politique. Souscription par l'Albanie de la Résolution du Kominform contre le Parti Communiste Yougoslave. Dénonciation des traités et protocols de commerce albano-yougoslave. Protestation yougolsaves, 10 lipca 1948, Archives. Affaires étrangères, Commerce extérieur et Coopération au développement (dalej AAE); nr dossier 12090, nr 387.

${ }^{7}$ J. Pirjevec, Tito and His Comrades, University of Wisconsin Press, 2018, s. 175.

${ }^{8}$ M. Djilas, Rozmowy..., s. 144.

${ }^{9}$ Decyzje te zapadły w Moskwie 6 czerwca 1946 r., a potwierdzone zostały 14 sierpnia 1946 r. na X (poszerzonym) plenum $\mathrm{KC} \mathrm{BPR}(\mathrm{k})$.

${ }^{10}$ G. Dimitrow, Dnewnik, (9 mart 1933-6 fewruari 1949), red. D. Sirkow, P. Boew, N. Awrejski, E. Kabakcziewa, Sofija 1997. 
Był to główny cel tego układu, na którym zależało nie tylko Dimitrowowi, ale i Stalinowi. Ze względu na nową sytuację polityczną, tj. po wkroczeniu wojska USA do Grecji, Moskwa z jednej strony chciała wyciszyć problem federacji na arenie międzynarodowej, z drugiej zaś za pośrednictwem Bułgarii zwiększyć kontrolę nad Jugosławią Tity ${ }^{11}$. Jednak Tito nadal prowadził rozmowy z Dimitrowem o federacji bałkańskiej. Dnia 17 stycznia 1948 r. Dymitrow, udzielając wywiadu z okazji podpisania układu sojuszniczego Bułgarii z Rumunią, zadeklarował możliwość stworzenia federacji obejmującej nie tylko państwa bałkańskie, w tym Grecję (gdzie toczyła się wojna domowa), ale również Węgry, Polskę, Czechosłowację ${ }^{12}$.

Belgrad podpisał także traktaty sojusznicze z Węgrami - 8 grudnia 1947 r. i Rumunią - 19 grudnia 1947 r. Dla Moskwy scenariusz, w którym Tito prowadził samodzielną politykę, był nie do przyjęcia, jako że stanowił zagrożenie dla sowieckiej dominacji. Wizję stosunków międzynarodowych Moskwa przedstawiła 22 września 1947 r. na konferencji przedstawicieli partii komunistycznych w Szklarskiej Porębie ${ }^{13}$.Wykluczała ona jakąkolwiek autonomię państw bloku wschodniego w kwestiach polityki zagranicznej. Narzędziem kontroli międzynarodowego ruchu komunistycznego stał się utworzony wówczas Kominform, czyli Biuro Informacyjne Partii Komunistycznych i Robotniczych ${ }^{14}$.

Swoje niezadowolenie w stosunku do aspiracji międzynarodowych Tity Stalin wyraził na tajnym sowiecko-jugosłowiańsko-bułgarskim spotkaniu, które odbyło się w Moskwie 10 lutego 1948 r. ${ }^{15}$ Uczestniczyli w nim Stalin, Wiaczesław Mołotow, Gieorgij Malenkow, Andriej Żdanow, Michaił Susłow i Walerian Zorin (ze strony Moskwy), poza tym Georgi Dimitrow, Wasił Kołarow, Trajczo Kostow (ze strony bułgarskiej), oraz Edvard Kardelj, Milovan Djilas, Vladimir Bakarić (ze strony jugosłowiańskiej). Mołotow - podkreślając, że konflikt między nimi [Sowietami - I.K.] a Jugosławią i Bułgarią jest poważny, podał trzy przykłady kwestii spornych: po pierwsze, zawarcie jugosłowiańsko-bułgarskiego traktatu o przyjaźni, współpracy i wzajemnej pomocy bez wcześniejszych konsultacji ze ZSRS ${ }^{16}$; po drugie, deklaracja Dimitrowa o federacji krajów Europy Środkowej i Bałkanów, w tym Grecji, bez konsultacji z ZSRS; po trzecie, planowane wprowadzenie jugosłowiańskich dywizji wojskowych do Albanii ${ }^{17}$. Ze spotkania wynikało zatem niezbicie, że stosunki między państwami

${ }^{11}$ Zob. I. Stawowy-Kawka, Rok 1947..., s. 149-151.

${ }^{12}$ E. Znamierowska-Rakk, ,Apogeum” zbliżenia poludniowosłowiańskiego po II wojnie światowej. Porozumienie Butgarii i Jugostawii w 1947 r. (1 sierpnia w Bled oraz 27 listopada $w$ Ewksinogradzie), Dzieje Najnowsze, 2005, nr 37/2, s. 55-84; eadem, Federacja Stowian poludniowych w polityce Bułgarii po II wojnie światowej. Korzenie. Próby realizacji. Upadek, Warszawa 2005; W. Walkiewicz, Stosunki bułgarsko-jugosłowiańskie 1941-1948. Uwarunkowania i implikacje, Warszawa 1988, s. 35.

${ }^{13}$ M.J. Zacharias, Powołanie Kominformu w 1947 r. Przyczyny, przebieg, skutki, Studia z Dziejów Rosji i Europy Środkowo-Wschodniej, R. 1996, t. XXXI, s. 95-115.

${ }^{14}$ H. Bogdan, Histoire des pays de l'Est, des origines à nos jours, Perrin, 1999, s. 433; H. Bartoszewicz, Polityka Zwiazku Sowieckiego wobec państw Europy Środkowo-Wschodniej w latach 1944-1948, Warszawa 1999, s. 322-324.

15 „Report of Milovan Djilas about a Secret Soviet-Bulgarian-Yugoslav Meeting”, February 10, 1948, History and Public Policy Program Digital Archive, Arhiv Josipa Broza Tita, Fond Kabinet Marshala Jugoslavije I-3-b-651, 11.33-40. Translated by Vladislav Zubok (National Security Archive) http://digitalarchive.wilsoncenter. org/document/117100, (dostęp: 20.01.2020).

${ }^{16}$ Sowieci twierdzili na spotkaniu, że o traktacie dowiedzieli się z prasy.

${ }^{17}$ Stwierdzenie to dotyczy jugosłowiańskiego zamiaru rozmieszczenia dywizji w Albanii, co jednak nigdy nie miało miejsca. 
demokracji ludowej są dozwolone tylko do granic interesów sowieckich i tylko za zgodą Stalina. Jak wspomina Djilas: „stało się widoczne, że dla przywódców sowieckich, z ich wielkomocarstwową mentalnością, a zwłaszcza z ich przeświadczeniem, że Armia Czerwona oswobodziła Rumunię i Bułgarię, oświadczenia Dimitrowa oraz brak dyscypliny i samowola Jugosławii są nie tylko herezja, ale negacją ,świętych” praw Związku Sowieckiego.

O pierwszym sporze w bloku komunistycznym świat dowiedział się 29 czerwca $1948 \mathrm{r}$. Prasa radziecka opublikowała tego dnia „Rezolucję Biura Informacyjnego o sytuacji w Komunistycznej Partii Jugosławii”" ${ }^{18}$, która została przyjęta kilka dni wcześniej na posiedzeniu przedstawicieli Kominformu w Rumunii. W rezolucji zarzucono przywódcom komunistycznym w Belgradzie m.in., że prowadzona polityka wewnętrzna i zagraniczna zasadniczo odbiega od linii „marksistowsko-leninowskiej”. Dnia 1 lipca 1948 r. Albania jako pierwsza wypowiedziała traktaty łączące ją z Jugosławią, a 4 lipca 1948 r. wykluczono Jugosławię z Kominformu ${ }^{19}$. Tito pozostał natomiast na stanowisku i bronił swojej pozycji, mając masowe wsparcie członków KPJ, co zostało ogłoszone na V Kongresie tej partii, który odbył się w dniach 21-29 lipca 1948 r. ${ }^{20}$

\section{Przyczyny konfliktu Stalin - Tito w belgijskich dokumentach dyplomatycznych}

W raporcie ${ }^{21}$ z 13 lipca 1948 r., skierowanym do ministra spraw zagranicznych Belgii Paula Henriego Spaaka, Jacques Smets, belgijski chargé d'affaires w Belgradzie, analizuje zarzuty przedstawione Jugosławii w rezolucji Kominformu. Stwierdza, że zawiera ona „nieścisłości i sprzeczności”. Ponadto podkreśla, że zarzuty pod adresem KPJ, dotyczące jej odejścia od linii „,marksistowsko-leninowskiej”, są nieprawdziwe oraz że to nie partie komunistyczne wchodzące w skład Kominformu wystapiły z oskarżeniami, ale Wszechzwiązkowa Komunistyczna Partia Bolszewików - WKP(b). Oznacza to zdaniem Smetsa, że prawdziwym powodem ataku na KPJ był fakt, iż „Tito nie chciał podporządkować się sposobowi działania narzuconemu twardo przez Moskwę w stosunku do państw satelickich. Interesy krajowe powinny zostać całkowicie podporządkowane Kremlowi”22. O ile belgijskiej dyplomacji nie było wiadomo, jakich konkretnie spraw dotyczył konflikt, to postawiła ona bardzo trafną diagnozę, że Tito doprowadził do sporu z Kremlem, gdyż chciał dyskutować z Sowietami na równiej stopie o problemach dotyczących swojego państwa i rozwiązywać je zgodnie z interesem krajowym.

18 „Prawda” 29 czerwca 1948 r. Tekst dokumentu zob. Rezolucja Biura Informacyjnego o sytuacji w Komunistycznej Partii Jugosławii, Przegląd Socjologiczny Sociological Review, 10, 562-569, 1948. http://bazhum. muzhp.pl/media//files/Przeglad_Socjologiczny_Sociological_Review/Przeglad_Socjologiczny_Sociological_Review-r1948-t10/Przeglad_Socjologiczny_Sociological_Review-r1948-t10-s562-569/Przeglad_Socjologiczny_Sociological_Review-r1948-t10-s562-569.pdf, (dostęp: 20.01.2020).

${ }^{19}$ M. Deszczyński, Wykluczenie Komunistycznej Partii Jugosławii..., s. 109-133.

${ }^{20}$ H. Stys, V Kongres Komunistycznej Partii Jugosławii z 1948 roku i jego znaczenie, Historia i Polityka, 2005, tom IV, s. 115 i n.

${ }^{21}$ J. Smets, Raport politique. Expulsion du Parti Communiste Yougoslave du Kominform. Rupture entre Moscou et Belgrade, 13 lipca 1948, Archives. Affaires étrangères, Commerce extérieur et Coopération au développement (dalej AAE); nr dossier 12090, nr 392.

${ }^{22}$ Ibidem. 
Dopiero raport ambasadora Belgii w Belgradzie Georgesa Delcoigne'a z 22 lipca 1948 r. ${ }^{23}$ odnosi się do jednej z konkretnych przyczyn konfliktu Tito-Stalin. Raport ten dotyczy wydanej w Ludowej Republice Macedonii rezolucji Centralnego Komitetu Komunistycznej Partii Macedonii (dalej KC KPM), która przyciągnęła uwagę dyplomacji belgijskiej, ponieważ Macedonia stanowiła słaby punkt Jugosławii w tym znaczeniu, że jej terytorium było zawsze powodem niezgody między Bułgarią a Jugosławią. Szczególne kontrowersje budziła również idea połączenia Macedonii jugosłowiańskiej, bułgarskiej i greckiej oraz stworzenie w ten sposób autonomicznego państwa macedońskiego. Za szczególnie ciekawy fragment rezolucji KC KPM Delcoigne uznaje właśnie ten dotyczący bułgarskich tendencji do utworzenia autonomicznego państwa macedońskiego. Bułgarscy „towarzysze” zostali oskarżeni w rezolucji KC KPM o mieszanie się w organizację i sprawy wewnętrze tej partii, o wysuwanie nieprawdziwych oskarżeń w stosunku do Tity i KPJ oraz przede wszystkim o zamiar utworzenia państwa macedońskiego, niezależnego od Jugosławii. Rezolucja ta pokazuje, że dyskusja na temat autonomicznej Macedonii toczyła się za kulisami, a w związku z zarzutami Kominformu ujrzała światło dzienne. Zdaniem Delcoingne’a rezolucja jest dowodem na:

„....wzrost antagonizmu między Serbami a Bułgarami dotyczącego Macedonii, antagonizmu, któremu jugosłowiańscy i bułgarscy przywódcy komunistyczni wielokrotnie zaprzeczali, nazywając kością niezgody wykreowaną przez dynastie i imperialistów, aby przeszkodzić bratnim narodom Jugosławii i Bułgarii w podaniu sobie ręki"24.

Jakiekolwiek działania Tity w sprawie Macedonii, delikatnej z punktu widzenia stosunków międzynarodowych, nie po myśli Kremla, były dla Stalina nie do przyjęcia. I o ile do czasu zwycięskich walk prowadzonych przez gen. Markosa Vafiadisa i jego armię Stalin popierał plany federacji, tak po wkroczeniu do Grecji wojsk USA zaczął dystansować się od tej polityki, aby w 1948 r. od niej odstąpić.

Stalina irytowały również autonomiczne decyzje Tity dotyczące Triestu. Belgijskie raporty dyplomatyczne zawierają tłumaczenie broszury rozpowszechnianej na konferencji dunajskiej, która miała miejsce w Belgradzie w 1948 r. Broszura ta mieściła w sobie listy KC WKP(b) do KC KPJ. Twierdzenia w niej zawarte miały pogrążyć Titę w oczach jego proradzieckich towarzyszy i ich zastraszyć. Moskwa oskarża w nich Titę o to, że chciał doprowadzić do wojny między Związkiem Sowieckim a Brytyjczykami i Amerykanami, aby odzyskać Triest ${ }^{25}$. W odpowiedzi Tito opublikował, również $\mathrm{w}$ formie broszury, listy KC KPJ do KC WKP(b). Powyższa broszura rozpoczyna się od 21-stronicowego tekstu wyjaśniającego, który w znacznej części dotyczy właśnie Triestu. Jako nieprawdziwe zostały wskazane oskarżenia przywódców jugosłowiańskich o pragnienie, aby Związek Sowiecki rozpoczął wojnę z powodu konfliktu o Triest. W broszurze wyjaśniono, że kiedy rozpoczął się spór dotyczący tego, czy wojska jugosłowiańskie powinny pozostać w mieście, a Brytyjczycy i Amerykanie żądali w formie ultimatum ich wycofania i rozpoczęcia negocjacji o podziale jego terytorium na strefy, wówczas rząd jugosłowiański, przystając

${ }^{23}$ G. Delcoigne, Rapport politique. Les discussions bulgaro-yougoslaves au sujet de la Macedoine. Révélations depuis la date historique du 28 juin 1948. Une des raisons du conflit entre Belgrade et Moscou, AAE, nr dossier 12090, nr 412.

${ }^{24}$ Ibidem.

${ }^{25}$ G. Delcoigne, Rapport politique. Différend Belgrade-Moscou, 16 września 1948, nr dossier 12090, nr 500 . 
na te żądania, rozpoczął rozmowy. Stało się tak tylko dlatego, jak tłumaczono w broszurze, że Jugosławia dążyła do pokoju. $Z$ tego też powodu przywódcy jugosłowiańscy podpisali traktat pokojowy z Włochami, choć uważali go za niesprawiedliwy. Stąd ich początkowe deklaracje, że jeśli Jugosławia nie odzyska Triestu, to nie wyrażą na powyższy traktat zgody. Tito uznawał traktat pokojowy za kompromis między wielkimi mocarstwami, nie zaś za sprawiedliwe rozstrzygnięcie. W broszurze wskazano, że Jugosławia mimo wszystko przystała na to rozwiązanie, bo tak jak Związek Sowiecki pragnęła pokoju, co nie oznacza, że była z niego zadowolona i uważała za słuszny ${ }^{26}$.

Autonomiczne decyzje Tity w sprawach międzynarodowych nie były na rękę Stalinowi. Uznawał bowiem suwerenność każdego z państw bloku wschodniego za czysto teoretyczna, co przejawiało się bardziej w czynach niż deklaracjach z jego strony, gdyż przyjmował, że każda demokracja ludowa powinna całkowicie zgadzać się z linią polityczną Moskwy. Tito natomiast uważał, że suwerenność państwa i jego interesy powinny być szanowane, gdyż socjalizm może być silny jedynie wtedy, gdy jest zakorzeniony w konkretnym państwie. Podejście Tity unaocznia zdanie zamieszczone przez Titę i Kardelja w napisanym w imieniu KC KPJ liście z 13 kwietnia 1948 r. do Stalina i Mołotowa: „...tak jak każdy powinien kochać Związek Sowiecki, miejsce narodzin socjalizmu, tak nikt nie może kochać mniej swojej socjalistycznej ojczyzny"27.

W liście tym Tito dowodził:

„Jeśliby niektórzy z nas nawet bardzo kochali kraj socjalizmu - ZSRS, to jednocześnie nikt $\mathrm{z}$ nas nie śmiałby mniej kochać własnego kraju, który również buduje socjalizm w konkretnym przypadku Federacyjnej Ludowej Republiki Jugosławii, za którą zginęło setki tysięcy najlepszych obywateli"28.

Konflikt Tito - Stalin dotyczył również kwestii ideologicznych. Chodziło przede wszystkim o lekceważenie przez Sowietów rewolucji jugosłowiańskiej. Moskwie przeszkadzało, że komuniści w Jugosławii stawiają w szeregu przywódców - Titę zaraz po Stalinie. Wyznaczenie Belgradu na siedzibę Kominformu tylko pozornie było wyrazem uznania dla rewolucji jugosłowiańskiej. Krył się za nim zamiar podporządkowania Jugosławii rzekomej międzynarodowej solidarności komunistycznej, faktycznie zaś hegemonii państwa sowieckiego ${ }^{29}$. Szukanie ,własnych dróg do socjalizmu” przez państwa satelickie Związku Sowieckiego było nie do zaakceptowania przez Stalina. Kwestie te poruszali dyplomaci belgijscy nie tylko w Belgradzie, ale również w Warszawie. Zdaniem Arthura Wautersa $^{30}$, ambasadora Belgii w Polsce: „na dyktaturę proletariatu praktykowaną we wszystkich państwach Europy Wschodniej nakłada się najwyższa dyktatura Moskwy. (...) To, czego chce Moskwa, to posłuszeństwo całkowicie monolityczne. Wszechwładza Sowietów została zagrożona przez jugosłowiański rozłam (...) ${ }^{{ }_{3} 1}$.

${ }^{26}$ Ibidem.

${ }^{27}$ Ibidem.

${ }^{28}$ Zob. także Dokumenti 1948, t. I, opr. V. Dedijer, Belgrad 1979, dok. 48, s. 239.

${ }^{29}$ M. Djilas, Rozmowy..., s. 110.

${ }^{30}$ Arthur Wauters, belgijski polityk socjalistyczny. W 1940 r. został powołany na szefa służb informacyjnych i propagandowych belgijskiego rządu na uchodźstwie. Pod koniec wojny został szefem służb informacyjnych Ministerstwa Spraw Zagranicznych. Był ministrem rolnictwa w efemerycznym rządzie Spaaka, następnie został mianowany ambasadorem Belgii w Warszawie w 1946 r., później ambasadorem w Moskwie w latach 1952-1955.

${ }^{31}$ A. Wauters, Raport skierowany do P. van Zeelanda, Rupture du pacte d'amitié polono-yougoslave, 4 października 1949, AAE; nr 392. 


\section{Skutki konfliktu Stalin - Tito w belgijskich dokumentach dyplomatycznych}

Jako pierwszą konsekwencję konfliktu na linii Tito - Stalin belgijskie raporty polityczne wysyłane z Belgradu podają zerwane relacje Jugosławii z Albanią. Albania podpisała rezolucję Kominformu przeciwko KPJ i wypowiedziała traktaty i protokoły dotyczące współpracy gospodarczej albańsko-jugosłowiańskiej oraz wydaliła jugosłowiańskich specjalistów. Belgijski raport polityczny z 10 lipca 1948 r. obejmuje cztery noty protestacyjne przesłane przez Jugosławię Albanii oraz ich analizę. Zawiera również informację, że w odpowiedzi na albańskie działania Jugosławia zlikwidowała Stowarzyszenie Albania-Jugosławia, którego działacze albańscy zostali wydaleni, a jugosłowiańscy przydzieleni do pracy w administracji. Miało to znaczenie dla wojny domowej w Grecji. Stowarzyszenie zajmowało się bowiem, pod pozorem współpracy kulturalnej albańsko-jugosłowiańskiej, przesyłaniem przez terytorium Albanii broni i amunicji gen. Markosowi Vafiadisowi. Jak na ironię, zerwanie stosunków albańsko-jugosłowiańskich przyniosło więc korzyść rządowi greckiemu, który był wielokrotnie nazywany przez komunistów „monarchistyczno-faszystowskim”.

Zdaniem J. Smetsa całkowite zerwanie stosunków albańsko-jugosłowiańskich oznaczało „,...porażkę polityki Tity i stanowiło niepowodzenie wizerunkowe”32. Niewielka Albania zrezygnowała ze współpracy z największym i najpotężniejszym państwem Półwyspu Bałkańskiego. Jednocześnie było to wyjątkowo niekorzystne dla Albanii ze względu na izolację geograficzną tego państwa. Stanowiło realizację polityki Stalina, który chciał całkowicie odizolować Jugosławię i zadać cios międzynarodowemu i krajowemu prestiżowi rządów Tity.

Odosobnienie międzynarodowe Jugosławii, które było skutkiem rezolucji Kominformu, oraz otwarty atak Moskwy na Belgrad nie przyniosły oczekiwanych przez Stalina skutków. W raporcie ${ }^{33}$ z 13 lipca 1948 r. Smets zwraca uwagę, że Jugosławia w wyniku konfliktu stała się w mniejszym stopniu zdominowana przez Moskwę i że Stalin nie osiągnął oczekiwanego rezultatu, czyli odsunięcia od władzy Tity i jego sojuszników: Kardelja, Djilasa i Rankovicia, zaś działanie Kominformu doprowadziło do skonsolidowania się rządu jugosłowiańskiego wokół szefa, który umocnił swoją pozycję.

Drugi raport J. Smetsa z tego samego dnia, czyli 13 lipca $1948^{34}$, dotyczy programu obrad V Kongresu KPJ. Dyplomata belgijski przywiązuje wagę do tego Kongresu jako do wydarzenia, które prawdopodobnie wzmocni pozycję Tity. Wskazuje, że mimo apelu Kominformu do ,zdrowych elementów” o pozbycie się zdrajców, tzn. Tity, Kardelja, Djilasa i Rankovicia, KPJ na Kongresie nie poparła oskarżeń sowieckich, uznając je za niesłuszne i krzywdzące. Belgijski raport potwierdził zatem jednolite stanowisko KPJ w sprawie zarzutów Kominformu. O słabości frakcji prosowieckiej w Jugosławii świadczy również artykuł załączony do raportu J. Smetsa z 15 lipca 1948 r. ${ }^{35}$, którego autorem był Moša

\footnotetext{
${ }^{32}$ J. Smets, Raport politique. Expulsion du Parti Communiste Yougoslave du Kominform. Rupture entre Moscou et Belgrade, 13 lipca 1948, AAE, nr dossier 12090, nr 392.

${ }^{33}$ Ibidem.

${ }^{34}$ J. Smets, Le Ve Congrès du Parti Communiste Yougoslave, 13 lipca 1948, AAE, nr dossier 12090, nr 393.

${ }^{35}$ J. Smets, Les discussions entre les parties communistes. Article de MošaPijade en faveur da la politique de Tito, 15 lipca 1948, AAE, nr dossier 12090, nr 394.
} 
Pijade, jeden z siedmiu członków Biura Politycznego KPJ i szara eminencja w rządzie Tity. Poza nim do Biura Politycznego należeli: Tito, Kardelj, Djilas i Ranković, wymienieni w rezolucji Kominformu jako zdrajcy, oraz Andrija Hebrang i Sreten Žujović. Dwaj ostatni zostali wykluczeni z partii jugosłowiańskiej i aresztowani ${ }^{36}$. Moša Pijade w swoim artykule, który ukazał się w „Borbie”10 lipca 1948 r., stwierdził, że zarzuty Kominformu są ,poważnym błędem historycznym”. Nadzieje Moskwy na to, że Pijade zostanie nowym przywódcą i skupi wokół siebie zwolenników całkowitego podporządkowania Kremlowi, okazały się płonne. W raporcie z 28 września 1948 r. ${ }^{37}$ Delcoigne zastanawiał się, jak mogło dojść do sytuacji tak niekorzystnej dla Moskwy. Jego zdaniem postawa przywódców jugosłowiańskich była do przewidzenia, a Kreml powinien się spodziewać ze strony Jugosławii gwałtownych protestów i manifestowania niezależności. Zdaniem Delcoigne'a Moskwa albo nie przypuszczała, że Tito będzie się tak stanowczo i otwarcie opierał wysuniętym oskarżeniom, albo uznała, że dzięki prosowieckim komunistom jugosłowiańskim, Tito, Kradej, Ranković i Djilas - „,zterej wielcy skazani na śmierć przez Kreml” - okażą się niegroźni. Ta ostatnia teza zakłada zorganizowanie spisku mającego usunąć Marszałka. Biorąc pod uwagę krnąbrność i upór Tity, trudno przyjąć, że Moskwa liczyła ze strony Tity na „wyznanie win”. Według Delcoigne’a, Stalin przewidywał natomiast, że dojdzie do zamachu stanu. Nie byłoby to możliwe bez jugosłowiańskiej armii. Na jej czele miał stanąć „Arso” Arsenije Jovanović, dowódca Sztabu Głównego Armii Jugosłowiańskiej oraz gen. Branko Petričevi-Kadja, por. Vlado Depčević (z zarządu politycznego armii), którzy rzekomo zorganizowali zamach stanu, planowany zaraz po V Kongresie. Według raportu Delcoigne'a, Jovanović miał spędzić dwa miesiące w Związku Sowieckim, przygotowując zmianę władzy. Został zabity w Belgradzie, a nie, zgodnie z oficjalnymi doniesieniami, podczas ucieczki na granicy z Rumunią. Jako potwierdzenie tego faktu Delcoigne podaje również, że istotna liczba wojskowych została zatrzymana, wszyscy oficerowie pozostawali pod obserwacją Urzędu Bezpieczeństwa Państwa (UDBA), działającego pod kierownictwem Rankovicia, linie telefoniczne i telegraficzne w całej Jugosławii zostały odcięte na 24 godziny, a ambasada sowiecka była pilnowana przez służby bezpieczeństwa. Potwierdza to teorię o istnieniu spisku przeciwko Ticie, jak też fakt, że Stalin działał w porozumieniu z jugosłowiańskimi komunistami, którzy zamierzali obalić rząd Marszałka ${ }^{38}$. Spisek generałów świadczył o tym, jak trudno było Ticie przeciwstawić się rezolucji Biura Informacyjnego i zdobyć poparcie komunistów jugosłowiańskich.

Z raportu Delcoigne'a z 30 września 1948 r. wynika, że obie strony konfliktu Moskwa - Belgrad podjęły działania, które nie zmierzały do jego złagodzenia. Jak pisze Delcoigne: „fosa między Moskwą a Belgradem pogłębia się coraz bardziej”. WKP(b) otwarcie nakłaniała do sprzeciwu wobec Tity i jego zwolenników, wezwała państwa satelickie do zrobienia tego samego, co skutkowało izolacją polityczną i ekonomiczną Jugosławii, ponadto przed-

${ }^{36}$ Andrija Hebrang zmarł w więzieniu w niejasnych okolicznościach, prawdopodobnie w 1949 roku. Oficjalny komunikat o jego śmierci władze jugosłowiańskie wydały dopiero 25 maja 1952 r. Sreten Žujović miał więcej szczęścia, przyznał się do winy i po dwóch latach więzienia został wypuszczony; I. Banac, With Stalin against Tito: Cominformist Splits in Yugoslav Communism, Cornell University Press, 2018, s. 122; J. Pirjevec, Tito and His Comrades, University of Wisconsin Press 2018, s. 188.

${ }^{37}$ G. Delcoigne, Rapport politique. Yougoslavie-Kominform, 28 września 1948, AAE, nr dossier 12090, nr 513.

${ }^{38}$ Ibidem. 
sięwzięła kampanię propagandową, rozpowszechniając listy Stalina do Tity i publikując w prasie sowieckiej i państw satelickich bardzo niepochlebne dla Marszałka artykuły. W organie prasowym Kominformu z 15 września 1948 r. znalazło się np. stwierdzenie o „klice Tity, która przerodziła się w bandę zabójców". W wyniku konfliktu Tito - Stalin pojawili się nowi „wrogowie ludu” - „titoiści”. Wauters w raporcie z 19 września 1949 r. stwierdza, że „herezja Tity nie jest już postrzegana jedynie jako odstępstwo. (...). Ruch Tity postrzegany jest w polskiej prasie jako rozległa organizacja międzynarodowa, opłacana dolarami amerykańskimi, rozciaggająca się na wszystkie kraje Wschodu, w celu obalenia państw demokracji ludowej i poddania narodów za żelazną kurtyną imperializmowi anglosaskiemu"39.

KPJ natomiast odrzuciła wszystkie zarzuty Kominformu, a Tito oczyściwszy rząd federalny i rządy wszystkich republik z „elementów” prosowieckich, pozostał na stanowisku.

Belgijscy dyplomaci zwracają również uwagę na fakt, że konflikt Tito - Stalin był ciosem wizerunkowym dla komunizmu. Smets w raporcie dotyczącym wyrzucenia KPJ z Kominformu ${ }^{40}$ pisze: ,przeciwnicy reżimu komunistycznego w Jugosławii i innych państwach demokracji ludowej, którzy dotąd wierzyli w monolityczną jedność partii, w całkowitą i bezwarunkową podległość Tity i innych radzieckich Quislingów, odkryli, że za kulisami przez wiele miesięcy dochodziło do poważnych sporów (...). To doświadczenie nie zostanie zapomniane, a dla »reakcjonistów« w krajach »demokracji ludowej« będzie ważny fakt, że takie nieporozumienia mogą się powtórzyć (...) i w ich następstwie Związek Sowiecki stracić może kolejne ujarzmione państwo".

Bardziej sceptyczny był ambasador belgijski w Warszawie. W raporcie dotyczącym zerwania układu o przyjaźni polsko-jugosłowiańskiej z 13 września 1949 r. ${ }^{41}$ uznał „walkę między Stalinem a Tito za poważną szkodę dla prestiżu tego pierwszego". Stwierdził jednak, że „byłoby przesadą mówić, iż blokowi komunistycznemu grozi rozpad”; niemniej zauważył pewne konsekwencje, jakie konflikt zrodził w Polsce. Zdaniem tego belgijskiego dyplomaty opór Jugosławii przeciwko Związkowi Sowieckiemu wywołał satysfakcję Polaków i zakłopotanie polskiego rządu, który potępienie KPJ i Tity przez Kominform uważał za błąd. Skutki konfliktu Tito - Stalin dla pozostałych państw bloku wschodniego były również żywo dyskutowane przez środowiska emigracyjne. ${ }^{42}$ Polska emigracja odebrała „bunt Tity” jako sygnał dla Anglosasów, że na monolicie bloku wschodniego dała się zauważyć poważna rysa ${ }^{43}$.

\section{Wnioski}

W belgijskich raportach dyplomatycznych poświęcono bardzo wiele uwagi wydarzeniom związanym ze sporem między Titą i Stalinem. Szczególnie istotne dla Belgii były

\footnotetext{
${ }^{39}$ A. Wauters, Raport skierowany do P. van Zeelanda, AAE, 19 września 1949, nr dossier12 419, nr 827.

${ }^{40}$ J. Smets, Raport politique. Expulsion du Parti Communiste Yougoslave du Kominform. Rupture entre Moscou et Belgrade, 13 lipca 1948, op.cit.

${ }^{41}$ A. Wauters, Raport skierowany do P. van Zeelanda, Vers la rupture de l'accord d'amitié polono-yougoslave, 13 września 1949, AAE, nr dossier 2561, nr 806.

${ }^{42}$ T. Wolsza, Obraz życia politycznego w Jugosławii w ujęciu polskiej emigracji politycznej w Wielkiej Brytanii - kluczowe zagadnienia (1945-1948), Dzieje Najnowsze, 2019, nr 1, s. 163-189.

${ }^{43}$ M.S. Wolański, Europa Środkowo-Wschodnia w myśli politycznej emigracji polskiej w latach 1945-1975, Wrocław 1996, s. 81-82.
} 
konsekwencje, jakie mogły wyniknąć z tego konfliktu dla innych państw satelickich Związku Sowieckiego, oraz ewentualna możliwość zmiany ustroju Jugosławii i jej zbliżenia do Zachodu. Belgijscy dyplomaci przyjęli, że niezależność Tity od Moskwy jest szczególnie niefortunnym, z punktu widzenia Stalina, przykładem dla pozostałych państw demokracji ludowej. Mimo to w raporcie z 2 maja $1949 \mathrm{r}^{44}$ słusznie uznali za nieprawdopodobną zarówno interwencję zewnętrzna, jako nieuzasadnioną wystarczająco z psychologicznego punktu widzenia, jak i możliwość przewrotu wewnętrznego. $Z$ belgijskich raportów dyplomatycznych wyraźnie wynika również, że konflikt Tity ze Stalinem nie doprowadzi do zmian ustrojowych w Jugosławii i zbliżenia tego państwa do mocarstw zachodnich. Jak deklaruje Delcoigne w raporcie z 30 września 1948 r.: „Tito i jego zwolennicy są i pozostaną komunistami niezależnie od okoliczności”45.

Zerwanie Jugosławii z ZSRS stanowiło przełom w stosunkach wewnętrznych krajów „demokracji ludowej” $i$ otwierało drogę do uwalniania się z jedynego, ,słusznego i sprawdzonego" modelu sowieckiego. Dla ideologów zachodnich stanowiło od strony teoretycznej wyzwanie skłaniające do bardziej elastycznej polityki wobec poszczególnych krajów ze strefy sowieckiej, aby wykruszać imperium na jego peryferiach. Realistyczne spojrzenie belgijskich dyplomatów, reprezentujących małe państwo i wyczulonych na politykę wielkich mocarstw, warte jest podkreślenia.

\section{Bibliografia}

Archiwa:

Archives. Service public federal Affaires étrangères, Commerce extérieur et Coopération au développement, $\mathrm{nr}$ dossier 12090.

Dokumenty drukowane:

Dokumenti 1948, t. I opr. V. Dedijer, Belgrad 1979.

Rezolucja Biura Informacyjnego o sytuacji w Komunistycznej Partii Jugosławii, Przegląd Socjologiczny Sociological Review 10, 562-569, 1948. http://bazhum.muzhp.pl/media//files/Przeglad_Socjologiczny_Sociological_Review/Przeglad_Socjologiczny_Sociological_Reviewr1948-t10/Przeglad_Socjologiczny_Sociological_Review-r1948-t10-s562-569/Przeglad_Socjologiczny_Sociological_Review-r1948-t10-s562-569.pdf

Wilson Center Digital Archive, Report of Milovan Djilas about a Secret Soviet-Bulgarian-Yugoslav Meeting," February 10, 1948, History and Public Policy Program Digital Archive, Arhiv Josipa Broza Tita, Fond Kabinet Marshala Jugoslavije I-3-b-651, 11.33-40. Translated by Vladislav Zubok (National Security Archive), https://digitalarchive.wilsoncenter.org/document/117100. pdf?v $=6 f 56 \mathrm{cb} 491530901 \mathrm{~cd} 72 \mathrm{ee} 384 \mathrm{~b} 256219 \mathrm{e}$

Pamiętniki:

Dimitrow G., Dnewnik, (9 mart 1933-6 fewruari 1949), red. D. Sirkow, P. Boew, N. Awrejski, E. Kabakcziewa, Sofija 1997.

Djilas M., Rozmowy ze Stalinem, Warszawa 1962.

\footnotetext{
${ }^{44}$ Reflexions sur la question Yougoslave, 2 maja 1949, AAE, nr dossier 12090, nr 124.

${ }^{45}$ Ibidem.
} 
Monografie:

Banac I., With Stalin against Tito: Cominformist Splits in Yugoslav Communism, Cornell University Press, 2018.

Bartoszewicz H., Polityka Zwiazku Sowieckiego wobec państw Europy Środkowo-Wschodniej w latach 1944-1948, Warszawa 1999.

Bobrowski C., Socjalistyczna Jugostawia, Warszawa 1957.

Bogdan H., Histoire des pays de l'Est, des origines à nos jours, Perrin, 1999.

Kastory A., Jugosławia w polityce Stanów Zjednoczonych, Wielkiej Brytanii i Zwiqzku Sowieckiego 1948-1956, Kraków 2018.

Nagy L., Démocraties populaires: du bloc soviétique au communisme des patries, Paris 1968.

Pirjevec J., Tito and His Comrades, University of Wisconsin Press, 2018.

Walkiewicz W., Stosunki bułgarsko-jugostowiańskie 1941-1948. Uwarunkowania i implikacje, Warszawa 1988.

Wolański M.S., Europa Środkowo-Wschodnia w myśli politycznej emigracji polskiej w latach 1945 1975, Wrocław 1996.

Zacharias M.J., Komunizm, federacja, nacjonalizmy. System władzy w Jugostawii 1943-1991, Warszawa 2004.

Artykuły:

Deszczyński M., Wykluczenie Komunistycznej Partii Jugosławii z Biura Informacyjnego Partii Komunistycznych i Robotniczych, Studia z Dziejów Rosji i Europy Środkowo-Wschodniej, 1993, t. XXVIII.

Kadić A., The Stalin-Tito Conflict as Reflected in Literature, Slavic Review, 1978, nr 37(1).

Perović J., The Tito-Stalin Split: A Reassessment in Light of New Evidence, Journal of Cold War Studies, 2007, Vol. 9, nr 2.

Stawowy-Kawka I., Rok 1947 w relacjach butgarsko-jugosłowiańskich w kontekście polityki Stalina i sytuacji międzynarodowej, Studia Środkowoeuropejskie i Bałkanistyczne, 2018, t. XXVII.

Stys H., V Kongres Komunistycznej Partii Jugosławii z 1948 roku i jego znaczenie, Historia i Polityka, 2005, t. IV.

Wolsza T., Obraz życia politycznego w Jugosławii w ujęciu polskiej emigracji politycznej w Wielkiej Brytanii - kluczowe zagadnienia (1945-1948), Dzieje Najnowsze, 2019, nr 1.

Zacharias M.J., Konflikt radziecko-jugosłowiański i przemiany ustrojowe w Jugosławii w latach 1948-1954, Dzieje Najnowsze, 1990, nr 4.

Zacharias M.J., Powołanie Kominformu w 1947 r. Przyczyny, przebieg, skutki, Studia z Dziejów Rosji i Europy Środkowo-Wschodniej, 1996, t. XXXI.

Znamierowska-Rakk E., „Apogeum” zblizenia poludniowosłowiańskiego po II wojnie światowej. Porozumienie Butgarii i Jugosławii w 1947 r. (1 sierpnia w Bled oraz 27 listopada w Ewksinogradzie), Dzieje Najnowsze, 2005, nr 37/2.

Znamierowska-Rakk E., Federacja Stowian południowych w polityce Butgarii po II wojnie światowej. Korzenie. Próby realizacji. Upadek, Warszawa 2005.

Inga Kawka, dr hab. (nr ORCID: 0000-0001-6909-5798), adiunkt w Katedrze Prawa Europejskiego na Wydziale Prawa i Administracji Uniwersytetu Jagiellońskiego. Autorka kilkudziesięciu publikacji z zakresu prawa Unii Europejskiej oraz publicznego prawa gospodarczego, w tym monografii: Telekomunikacyjne organy regulacyjne w Unii Europejskiej (Kraków 2006), Zasady dobrego rzqdzenia w prawie Unii Europejskiej. Sektory infrastrukturalne (Kraków 2011), Gospo- 
darcza działalność usługowa $w$ prawie polskim $w$ świetle unijnych swobód przedsiębiorczości i świadczenia ustug (Kraków 2015), oraz we współautorstwie z M. Kożuch - Prawne aspekty świadczenia ustug $w$ Szwajcarii przez małe i średnie przedsiębiorstwa z Unii Europejskiej (Kraków 2018).

inga.kawka@uj.edu.pl 